\title{
Adapted REDD plus Based on Local People's Capabilities: A Case Study from Luang Prabang Province, Lao PDR
}

\author{
Marie Iwadare1, Motoshi Hiratsuka ${ }^{2 *}$ \\ ${ }^{1}$ Mitsubishi UFJ Research and Consulting, Tokyo, Japan \\ ${ }^{2}$ Faculty of Human Sciences, Waseda University, Saitama, Japan \\ Email: ^hiratsuka@waseda.jp
}

How to cite this paper: Iwadare, M., \& Hiratsuka, M. (2017). Adapted REDD plus Based on Local People's Capabilities: A Case Study from Luang Prabang Province, Lao PDR. Open Journal of Forestry, 7, 228241

https://doi.org/10.4236/ojf.2017.72014

Received: March 8, 2017

Accepted: April 15, 2017

Published: April 18, 2017

Copyright $\odot 2017$ by authors and Scientific Research Publishing Inc. This work is licensed under the Creative Commons Attribution International License (CC BY 4.0).

http://creativecommons.org/licenses/by/4.0/

\begin{abstract}
The reducing emissions from deforestation and forest degradation (REDD plus) has been proposed as a key tool for reducing greenhouse gases (GHG) from deforestation and forest degradation in land use sector. The development of a REDD plus that considers national, sub-national, and/or local circumstances in relation to a target area requires an analysis of site-specific deforestation drivers and land use characteristics. This study aimed to analyze the capability of forest-dependent people to find the way for reducing pressures on forest resources, i.e. reducing shifting cultivation and identified their patterns of land and forest use, as this knowledge is essential for developing a REDD plus for land and forest management for an area. The study target area was Luang Prabang Province in the northern part of the Lao People's Democratic Republic (Lao PDR). We conducted questionnaire-based surveys and participatory workshops to identify the drivers of deforestation and forest degradation as well as current local capabilities. Our findings, which focused on the characteristics of ethnic groups (Khmu and Hmong) and the agricultural techniques used by villagers, revealed significant differences between upland rice farmers without paddy fields and farmers with paddy fields who cultivated upland rice in terms of their capabilities to maintain livelihoods. The results of a discriminant function analysis indicated that $66.7 \%$ of the initially categorized respondents were correctly classified for the variable $\mathrm{Khmu}$ or Hmong and $82.1 \%$ classified for the variable upland rice farmers with paddy or upland rice farmers without paddy. The results indicated a lower capability to transition to alternative livelihoods among farmers relying on upland cultivation (i.e. shifting cultivation) than among farmers who cultivate paddy. Moreover, the study revealed the importance of applying a capability approach when planning REDD plus in Lao PDR that account for differential capabilities attributed to ethnicity or other vulnerable group statuses.
\end{abstract}




\section{Keywords}

Capability Approach, Capacity Building, Deforestation Drivers, Safeguards

\section{Introduction}

Since 1990s, the highest deforestation has been occurred in Southeast Asia (FAO, 2010; Harris et al., 2012). However, even in now, efforts have been underway to address deforestation and forest degradation resulting from human-induced activities in many countries (Fujisaki et al., 2016). Therefore key factors which should improve to deal with deforestation drivers, and effective institution, appropriate legislation, and participation of stakeholders including local community, and so on, have been pointed out in such countries (Hiratsuka et al., 2014; Hiratsuka et al., 2016). As an international framework to address deforestation and forest degradation in such region, the reducing emissions from deforestation and forest degradation (REDD plus) was adopted as one of the climate change mitigation measures under the United Nations Framework Convention on Climate Change (UNFCCC) (UNFCCC, 2007), and the most of developing countries had started readiness activities of REDD plus according to the application of a three-phased approach comprising readiness (preparation), demonstration (trial), and implementation (full implementation), which was adopted in the sixteenth session of the Conference of the Parties (COP16) to the UNFCCC (UNFCCC, 2011). However, the lack of experiences and good practices of REDD plus readiness in both of developed and developing countries makes it very difficult to conduct adaptive capacity development, such as technology transfer (e.g., forest monitoring technique) or other individual activities (e.g., livelihood improvement), based on capability approach (Sen, 1992) in forest conservation project including REDD plus (Yamanoshita \& Amano, 2012) which aims to develop "capabilities" and "functionings" of rural people to accept and implement REDD plus project, even in the importance for considering human capability, including marginalized communities was pointed out as the key issues of REDD plus (Patel et al., 2013), and also the importance of the participation of all stakeholders within the community was pointed out by previous study on forest project (Yamanoshita \& Amano, 2012). Additionally in relation to the above points, it was evident that it is required the application of corresponding methods of readiness (preparation) in REDD plus taking into account the specific context of the target site (Umemiya et al., 2011).

Within Southeast Asia, Lao People's Democratic Republic (Lao PDR) has the highest proportion of forests (forest cover of approximately $81 \%$ in 2015 based on the forest definition of Food and Agriculture Organization of the United Nations (FAO) (FAO, 2010)), which are an essential component of the national economy as well as of personal livelihoods. The country's economy and over $70 \%$ of population depends on natural resources for their livelihoods and to ensure food security. The agriculture sector is responsible for approximately $30 \%$ 
of GDP and approximately $70 \%$ of the population is dependent on the sector for their livelihoods (Government of Lao PDR, 2015). However, during the past two to three decades, severe deforestation and forest degradation have occurred; forest cover in middle 1960s was estimated around 70\% (Government of Lao PDR, 2005 ) and it was decreased approximately $40.2 \%$ in 2010 (Government of Lao PDR, 2011). The primary causes or drivers of these processes of deforestation and forest degradation are agricultural expansion, namely, pioneering shifting cultivation (involving clearance of rich forests) and conversion of forest to agricultural concessions, and industrial plantations (Government of Lao PDR, 2011). In spite of such a situation of deforestation and its drivers, shifting cultivation has been dominant land use system in the northern Lao PDR, securing the livelihoods of the large percentage of the rural population living in mountainous area (Heinimann et al., 2013).

From considering such situations of REDD plus in Lao PDR, this study aimed to clarify the key points of REDD plus in phase of readiness (preparation), from assessing local circumstances or the capabilities of local people in relation to their diverse characteristics (ethnicity, or other vulnerable group statuses) to increase their participation in the REDD plus project.

\section{Study Site}

The study site was Houaykhing village, within the Houaykhing Village Cluster in Phonsay District, LuangPrabang Province, where had been under the project focusing on the readiness (preparation) up to 2015 which entitled "Participatory Land and Forest Management Project for Reducing Deforestation in Lao PDR (PAREDD)" by Japan International Cooperation Agency (JICA) (JICA, 2014). Most of the rural people of the region rely on slash-and-burn agriculture, and the food supply mainly comprises upland rice and other vegetables.

This site is located in a mountainous area and its area is approximately 7400 ha (Figure 1) with a mean altitude of $908 \mathrm{~m}$ above sea level (a.s.l.) (ranging from 324 to $2106 \mathrm{~m}$ a.s.l.) and a mean slope of 12.6 degrees in Phonxay district. The mean monthly high temperature ranges from $26.5^{\circ} \mathrm{C}$ in December to $34.6^{\circ} \mathrm{C}$ in April, whereas the mean monthly low temperature ranges from $14.2^{\circ} \mathrm{C}$ in January to $24.3^{\circ} \mathrm{C}$ in July. Annual rainfall is $966.8 \mathrm{~mm}$ (with a monthly low of 0.0 $\mathrm{mm}$ in January and February and a monthly high of $264.5 \mathrm{~mm}$ in August) in Phonxay district. Its location is around $105 \mathrm{~km}$ north of the city of LuangPrabang, approximately a three and a half hour drive in dry season. During the rainy season, especially from July to September, this village is not always accessible by road.

From December 2011 to August 2015 this village was one of the target areas of a PAREDD by JICA (JICA, 2014). This project was designed to promote REDD plus readiness (preparation). As a readiness in village level, the project had implemented following activities: awareness raising of forest conservation, demonstration of alternative livelihood according to villagers' needs and ability, establishing village fund and organizing the land and forest management committee 


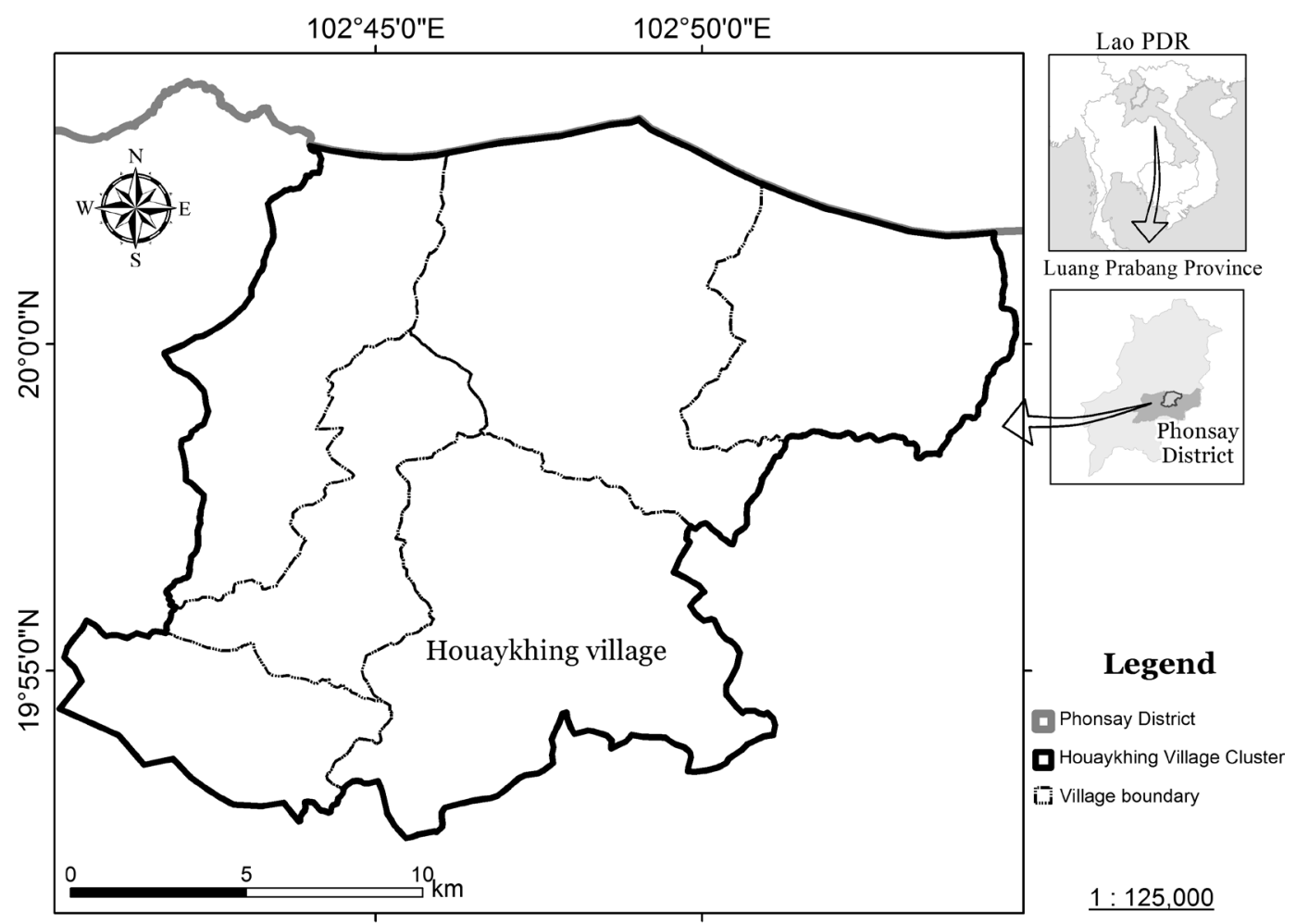

Figure 1. Location of Houaykhing village, Phonsay District, Luang Prabang Province.

(LFMC) for forest management. In addition, a REDD plus demonstration study funded by the Ministry of the Environment Japan under the Joint Crediting Mechanism (JCM) was conducted in 2014.

In 2003, the consolidation of four villages within a central location, as part of the Government's rural development policy, resulted in the relocation of Houaykhing village alongside a main road. The total population of the village consequently increased from 165 households (around 1200 persons, 16.2 persons per $\mathrm{km}^{2}$ ) in 2003 to 229 households (around 1520 persons, 20.5 persons per $\mathrm{km}^{2}$ ) in 2014. The village comprises two major ethnic and cultural groups: the Khmu and the Hmong. There are $128 \mathrm{Khmu}$ households and $96 \mathrm{Hmong}$ households, respectively. Additionally, there are only five Lao Loum households. Lao PDR is multi-ethnic country and classified three groups by geographically: Lao Loum (lowland), Lao Theung (Upland Lao) and Lao Soung (Highland Lao). Lao Loum is mainstream and the Khmu and the Hmong belong to Lao Theung and Lao Soung in each (IFAD, 2012). In a custom, both of Khmu and Hmong, almost entirely of households are engaging shifting cultivation of upland rice and raising livestock by free grazing in the forest or their fallow area in this study site (JICA, 2014) and livelihood of them relies on slash-and-burn agriculture, and the food supply mainly comprises upland rice and other vegetables. Annual household income in the Houaykhing village was 22,079 thousand kip (around 2699 USD) and over $75 \%$ of it was from Agriculture (Crops: 17\%, NTFPs: $8 \%$ and Livestock: 51\%) (Champa Lao, 2015).

Most of forests in Houaykhing village are categorized as secondary forest after 
shifting cultivation (i.e. fallow area) and mixed deciduous/evergreen forest (mixed forests). An analysis of satellite imagery of Houaykhing Village Cluster revealed that significant portions of mixed forests were converted to slash-andburn area or to fallow area between 1996 and 2010 (JICA, 2014). This analysis indicated that mixed forests have decreased (their 2010 level was approximately $72 \%$ of their 1996 level). Conversely, slash-and-burn and fallow areas have increased (their 2010 levels were approximately 162\% of their 1996 level) (Figure 2).

\section{Methodologies}

\subsection{Questionnaire-Based Survey}

Individual interviews were conducted using a questionnaire (see detail is following) to identify drivers of deforestation, forest degradation, and livelihood conditions in the village. With keeping number of sampled households over 15\% to the total, 39 households ( $18 \%$ of the total 220 households in the village, October 2012) were selected through stratified sampling (not complete census) in two steps. Stratification was conducted to ensure that data collection included poor households as well as balanced representation of the two main ethnic groups using basically village information. Around the study site, poor household is defined by village judge based on livelihood, labor forces, number of children, land possession and so on, although the Government of Lao PDR defines 'poor household' as a household whose income is under 180,000 kip (around 22 USD) per month in rural area by Prime Minister Decree 285/2009 on Poverty and De-

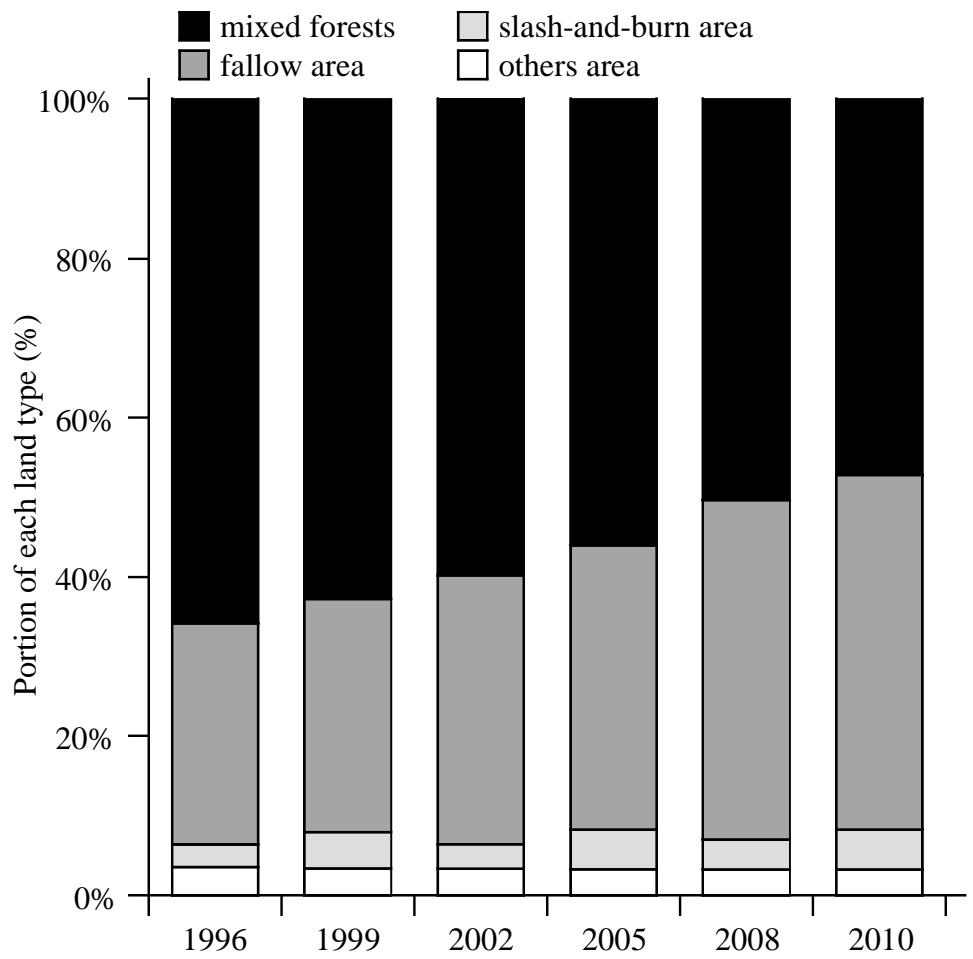

Figure 2. Land and forest area dynamics according to four classification (mixed forests, fallow area, slash-and-burn area and other area) from 1996 to 2010 in Houaykhing Village Cluster (adapted from (JICA, 2014)). 
velopment (Champa Lao, 2012).

The survey comprised three main informational components: a) basic information, occupations, and incomes: b) land use changes; and c) awareness and capability in relation to forest management and personal livelihoods. Part (c) was further broken down into six sub-topics: decision making, cooperation among villagers (group activities), use of forest resources, current livelihoods, daily life situation (e.g., health facilities and water resources), and livelihood needs. Individual questionnaire-based surveys were conducted from October 2012 to January 2013.

To identify differences in local people's capabilities related to maintaining livelihoods and managing forests according to their ethnicity and farming styles, discriminant function analysis was performed using SPSS Software Version 21.0 (IBM Corp., Armonk, NY). The primary data used for the analysis were derived from individual interviews (the sampling survey) on land use, decision making, group activities, and current livelihoods. The responses provided by the sampled households on each topic were used as explanatory variables. These households were subsequently classified according to these variables and categorized as belonging to either the Khmu or Hmong ethnic groups. They were further grouped as "Upland rice farmers with paddy (URF with P)" or "Upland rice farmers without paddy (URF without $\mathrm{P}$ )". We then assessed the capacity building required for each group.

\subsection{Participatory Workshops}

In addition to conducting the above surveys, we also conducted participatory workshops as supplemental survey of questionnaire-based survey to obtain data on current land use practices and causes of deforestation and forest degradation. The interviews held with sampled households were aimed at ascertaining land use change, including land area and plots in use (a unit under shifting cultivation of around 1 ha in area). Also participatory workshops were held to identify barriers of improved land use, i.e. problem analysis according to the procedure of project cycle management (PCM) (European Commission, 2004), of each stakeholder of land and forest management mentioned in Table 1 below and their needs of improved livelihood under the REDD plus to the replacement of shifting cultivation by alternative livelihoods in the study site. A total of 22 participants who were not completely same as questionnaire-based survey attended the three-day workshops. Various people were involved in this workshop such as Khmu, Hmong, women, and poor household. These supplemental surveys were conducted from November 2012 to February 2013 and from May to June 2013 and from November 2014 to February 2015.

\section{Results and Discussion}

\subsection{Land-Use Changes and Deforestation Drivers}

From problem analysis of land use and land use change in the village, all of stakeholder mentioned that the main livelihoods connected with land use and 
Table 1. Characteristics of stakeholders of REDD plus project and results of participatory workshop (results of problem analysis obtained from workshops).

\begin{tabular}{lll}
\hline \multicolumn{1}{c}{ Type of stakeholders } & \multicolumn{1}{c}{$\begin{array}{c}\text { Characteristics of stakeholder and reasons of } \\
\text { selection for workshop }\end{array}$} & \multicolumn{1}{c}{ Results of problem analysis } \\
\hline Farmers (mainly household heads) & $\begin{array}{l}\text { They depend on shifting cultivation which had } \\
\text { been changed from traditional to short-term } \\
\text { rotation cycle. }\end{array}$ & $\begin{array}{l}\text { Cultivation of with a short rotation cycle makes their } \\
\text { productivity decrease; no irrigation system; limited } \\
\text { agricultural techniques (e.g. without fertilizer). }\end{array}$ \\
Women Union (Women group) & $\begin{array}{l}\text { They are thinking future development plan } \\
\text { from viewpoints of mother and children }\end{array}$ & $\begin{array}{l}\text { No irrigation system; no options of house works such } \\
\text { as weaving. }\end{array}$ \\
Village authority & $\begin{array}{l}\text { They understand village's history, land use and } \\
\text { livelihoods. }\end{array}$ & $\begin{array}{l}\text { No supports of irrigation system and obviously } \\
\text { dependent on shifting cultivation with short term; free } \\
\text { grazing and expansion of grazing land. }\end{array}$ \\
District Government staff & $\begin{array}{l}\text { They understand difference of working } \\
\text { conditions between inside and outside of village. }\end{array}$ & $\begin{array}{l}\text { Lack of knowledge and market information; dependent } \\
\text { on shifting cultivation with short term; villagers mainly } \\
\text { dependent on middlemen to sell products. }\end{array}$ \\
\hline
\end{tabular}

land use change in the village were shifting cultivation of upland rice using the short-term rotation method (three to four year fallow cycle in this village), and such shifting cultivation was identified as main driver of deforestation (Table 1). From satellite imagery analysis, such trend of deforestation and increase of shifting cultivation area was validated (Figure 2).

Regarding rotation period of the shifting cultivation, previous study targeting similar region (Lestrelin \& Giordano, 2007) mentioned that fallow cycle was decreased from approximately 10 years in the 1970s to around three years in 2003 because of the government policy to limit the land use, even in more than 7 years fallow cycle is necessary to get enough production of rice (Funakawa et al., 2011). As well as this village, villagers claimed in the interviews through questionnaire-based survey and workshops that their fallow period become shorter from around 10 years to 3 to 4 years during a few decades and cannot get enough production because of short rotation. Such short rotation brings that forest carbon decrease or forest degradation had occurred in the region. It is resulted that change of shifting cultivation practices was identified as most critical drivers of deforestation and forest degradation.

The results of interviews through questionnaire-based survey and workshops indicated that the number of plots for shifting cultivation in Houaykhing village increased after the year 2003's consolidation of villages within relocation (Figure 3 ). This was because of the increase in the population ( 165 households in 2003 to 229 households in 2014) that resulted from new arrivals seeking better access to main roads and cultivable land; main road from Phonsay District center to study site was improved in 2003 and extended to next province (Xiengkhuan Province) in 2009. As Figure 2 mentioned, "slash-and-burn area" and "fallow area" were increased instead of "mixed forests".

\subsection{Underlining Causes and Needs of Improved Livelihood under the REDD plus as Alternatively}

A further examination through interviews revealed that the underlying causes 


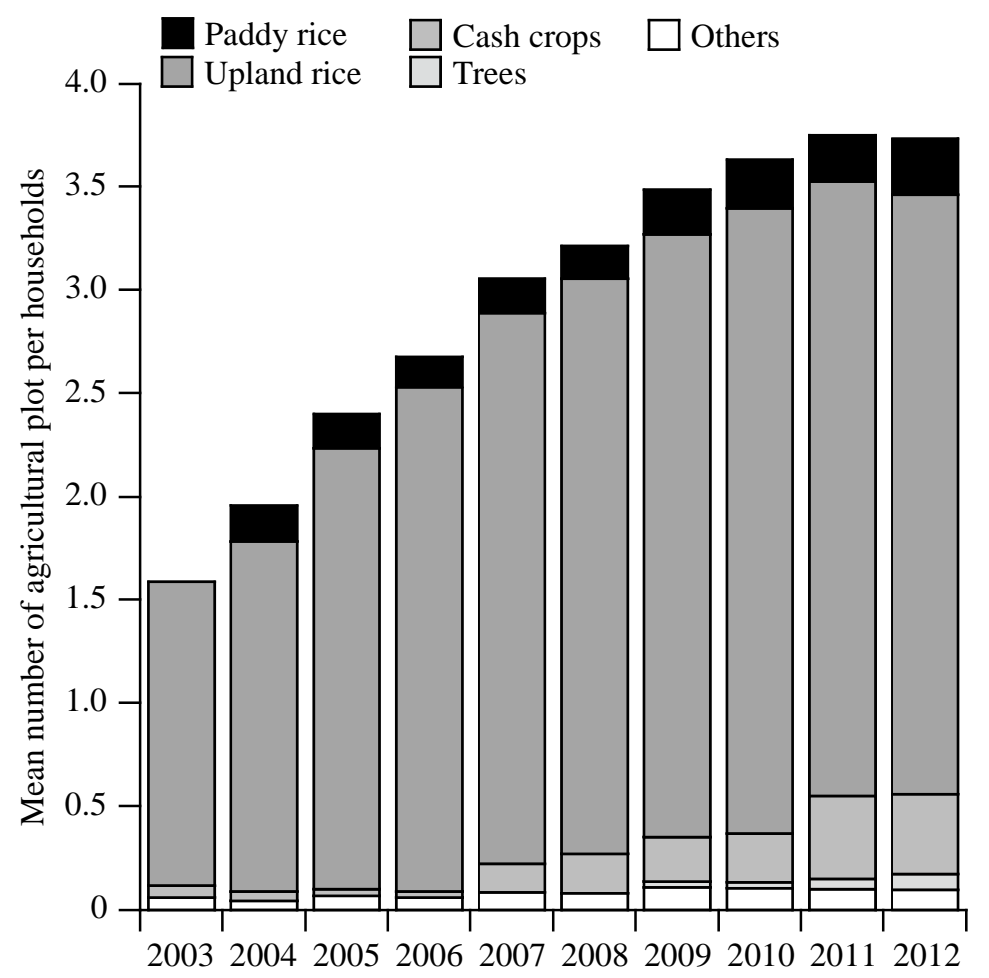

Figure 3. Historical mean number of agricultural plots used by household their planted plant types in Houaykhing village.

for these practices was resulted as the low capability (limited ability and technique to accept and implement livelihood options) of local people in the village who attributed to a lack of knowledge regarding suitable farming/livestock management, a lack of market facilities for agricultural products, limited group activities among villagers, and an absence of appropriate land and forest management systems such as key management groups. Consequently, they have no experiences in the use of agricultural techniques such as sloping land agriculture (permanent agriculture on terrace fields with mixed crops), composting, double cropping, and paddy cultivation.

In each livelihood in the village, their threat level and the needs of improved points regarding land use under the REDD plus (REDD plus activities) are summarized in Table 2. Key priorities for villagers were: improving livestock raising and changing cultivated crops, conversion from upland rice to paddy using irrigation systems and non-shifting agriculture based on the cultivation of coffee, fruits, and medicinal herbs.

\subsection{Identification of Corresponding Alternative Livelihood to Reduce Pressures on Forest Resources based on Capability}

Expanding the fallow period for shifting cultivation is one of the mitigation activities of Climate Change (JICA, 2014), and capability to engage in sustainable forest management and reduce shifting cultivation varies according to ethnicity and livelihood classifications among local people. Corresponding REDD plus activities, i.e. alternative livelihood to reduce pressures on forest resources, were 
should be based on not only needs of local people (Table 3 ) but also on capability of each ethnic group and their situation which is depending on shifting culti-

Table 2. Current livelihood and their threat levels and needs of improved livelihood and land use under the REDD plus (REDD plus activities) in Houaykhing village.

\begin{tabular}{|c|c|c|}
\hline Livelihood & Threat level $^{\mathrm{a}}$ & Needs of improved livelihood under the REDD plus (REDD plus activities). \\
\hline Shifting cultivation & High & $\begin{array}{l}\text { Increase of productivity through the introduction of new techniques such as sloping land agriculture } \\
\text { and composting; efficient land use during the dry season such as double cropping of vegetables with } \\
\text { composting. }\end{array}$ \\
\hline Paddy cultivation & Low & $\begin{array}{l}\text { Improvement of productivity through the introduction of new methods (composting and a water } \\
\text { management system); shift from mixed paddy and shifting cultivation to intensive paddy cultivation. }\end{array}$ \\
\hline Cash crop production & Middle & $\begin{array}{l}\text { Introduction of high value vegetables, fruits, and cash crops in the village; efficient land use during } \\
\text { the dry season. }\end{array}$ \\
\hline $\mathrm{NTFPs}^{\mathrm{b}}$ production & Low & Abundant forest resources with high value NTFPs that can be managed and produced commercially. \\
\hline Livestock raising & Middle & Suitable livestock management system; easy collection of manure for making compost. \\
\hline Market system & None $e^{c}$ & $\begin{array}{l}\text { Improved roads and market accessibility; opportunity to establish village markets with neighboring } \\
\text { villages. }\end{array}$ \\
\hline
\end{tabular}

a. Threat level is based on 3 levels ("high" means it is very hard to continue current life system, "middle" means it is difficult to continue current life system without support from outside, and "low" means it is difficult to continue current life system without some improvement by themselves); b. NTFPs means non-timber forest products such as fuel-wood, mushroom, fruits and so on; c. Market system is indirect to livelihood in the village and is quite a new for local people (threats level is nor analyzed).

Table 3. Three categorized explanatory variables used for discriminant function analysis.

\begin{tabular}{|c|c|c|}
\hline \multicolumn{2}{|c|}{ Explanatory variables to analyze the capability a) to c) ${ }^{\mathrm{a}}$} & Content \\
\hline \multirow[t]{7}{*}{ (a) } & Upland rice area (ha) & Total land area used for upland rice farming, including fallow land. \\
\hline & Upland rice plots (plots) & Total number of upland rice plots, including fallow land. \\
\hline & Productivity (kg per ha) & Productivity of upland rice per ha. \\
\hline & Annual production $(\mathrm{kg})$ & Total annual production from upland rice and paddy with rice husk. \\
\hline & Rice shortage (months) & Period of shortage of rice for family consumption. \\
\hline & Farming technique $\left(5\right.$ levels $\left.^{\mathrm{b}}\right)$ & Satisfaction level regarding farm technique owned by them. \\
\hline & Farming water ( 5 levels $\left.{ }^{b}\right)$ & Satisfaction level regarding the water situation for farming. \\
\hline \multirow[t]{4}{*}{ (b) } & Attendance of discussion (5 levels ${ }^{c}$ ) & Frequency of attendance at village meeting in a year. \\
\hline & Expressing opinion $\left(5\right.$ levels $\left.^{\mathrm{d}}\right)$ & Frequency of expressing opinion in the village meeting. \\
\hline & Understanding of discussion (5 levels ${ }^{\mathrm{e}}$ ) & $\begin{array}{l}\text { Identification level of discussion following three topics in the village meeting; land } \\
\text { use plan in a village, agriculture problem, and forest management. }\end{array}$ \\
\hline & Opinion for discussion process $\left(5\right.$ levels $\left.{ }^{\mathrm{f}}\right)$ & $\begin{array}{l}\text { Assessment for the necessity and beneficiary on bottom-up decision making process } \\
\text { on land use plan in village. }\end{array}$ \\
\hline \multirow[t]{2}{*}{ (c) } & Frequency of cooperation (5 levels ${ }^{\mathrm{g}}$ ) & $\begin{array}{l}\text { Frequency level of cooperation with other villager at following activity; improving } \\
\text { community infra such as meeting room and school, slash and burn operation, and } \\
\text { securing farming water. }\end{array}$ \\
\hline & Benefit of cooperation ( 5 levels ${ }^{\mathrm{h}}$ ) & $\begin{array}{l}\text { Recognition level for the benefit of group activity by following reason; efficiency for } \\
\text { farming (sharing labor force), knowledge sharing. }\end{array}$ \\
\hline
\end{tabular}

a. These data for each variable were obtained from interviews conducted with the sampled households in 2012; b. One (1) denotes the lowest satisfaction level, 3 is the middle level, and 5 is the highest satisfaction level (these were assessed by the sampled households); c. One (1) is no attendance, 3 is a half attendance, 5 is full attendance at regular meeting in a year; d. One (1) is no experience, 3 is making statement at every 2 times interval of meeting, 5 is making statement at every meeting; e. One (1) is lowest understanding, 3 is the middle level, and 5 is the highest understanding; f. One (1) is the lowest level, 3 is the middle level, 5 is the highest level (well understanding to use the bottom-up process); g. One (1) is never cooperate, 3 is the middle level, 5 is the highest level; h. One (1) is the lowest assessment, 3 is the middle, and 5 is the highest level. 
vation (slash-and-burn agriculture). Then difference of their capability were identified for the village based on discriminant function analysis with respect to following three capabilities: (a) land use and farm techniques relating to upland or paddy rice cultivation; (b) consciousness of decision making; and (c) consciousness of group activities/cooperation among villagers, using the explanatory variables (Table 3 ).

\subsubsection{Differences in Each Group's Capability on Land Use}

Differences in capabilities were analyzed according to farming style of URF with $\mathrm{P}$ and URF without $\mathrm{P}$, i.e. above (a) land use and farm techniques relating to upland or paddy rice cultivation. Results relating to farming style are shown; in the accuracy of discriminant rate (Table 4), it was identified whether each group (URA with P and URA without P) had different capability to sustain the livelihood (e.g., the farmer's annual rice production is $2326 \mathrm{~kg}$ and the later is $1926 \mathrm{~kg}$ ).

Also it was recognized what explanatory variables effect (Table 5) to divide

Table 4. Descriptive statistics (average and standard deviation values) of each explanatory variable regarding each group.

\begin{tabular}{cccc}
\hline Objective variable & Explanatory variable & Average & Standard deviation \\
\hline & Upland rice area (ha) & 3.996 & 1.836 \\
& Upland rice plots (plots) & 3.231 & 1.142 \\
& Productivity (kg per ha) & 1,665 & 626.9 \\
Upland rice farmers without & Annual production (kg) & 1,926 & 756.1 \\
paddy land 28 samples & Rice shortage (months) & 1.385 & 1.675 \\
& Farming technique (5 levels) & 2.654 & 1.231 \\
& Farming water (5 levels) & 1.577 & 1.301 \\
\hline & Upland rice area (ha) & 3.067 & 1.773 \\
& Upland rice plots (plots) & 3.000 & 1.225 \\
& Productivity (kg per ha) & 1,590 & 529.3 \\
Upland rice farmers with & Annual production (kg) & 2,326 & 654.0 \\
paddy land 11 samples & Rice shortage (months) & 1.778 & 2.279 \\
& Farming technique (5 levels) & 2.667 & 1.225 \\
& Farming water (5 levels) & 1.889 & 1.167 \\
\hline
\end{tabular}

Table 5. Standardized canonical discriminant function coefficients.

\begin{tabular}{cc}
\hline Explanatory variable & Function \\
\hline Upland rice area (ha) & 1.479 \\
Upland rice plots (plots) & -1.017 \\
Productivity (kg per ha) & 0.815 \\
Annual production (kg) & -0.984 \\
Rice shortage (months) & -0.165 \\
Farming technique (5 levels) & 0.149 \\
Farming water (5 levels) & -0.406 \\
\hline
\end{tabular}


two groups and interpret the feature and/or superiority of capability in each group, that is to say, function corresponds with features of each group that URF with $\mathrm{P}$ whose tends to be low (negative values) in "Upland rice plots" and "Annual production", while URF without P tends to be high in "Upland rice area.

The results of the discriminant function analysis regarding land use and farm techniques for upland or paddy rice cultivation indicated irregularities in the classification of both URA with P and URA without P. The overall correct classification rate was $82.1 \%$ (63.6\% of those reported to be URA with P; 7 out of 11 samples were classified correctly and $89.3 \%$ of those reported to be URA without P; 25 out of 28 samples were classified correctly). From such difference of capability regarding land use or, it was indicated that a first step may target URA without $\mathrm{P}$, who were categorized as having capability expect for shifting cultivation, and required to begin to alternative livelihood of raise small livestock such as chicken, goats, or pigs with the provision of appropriate technical support, as well as to initiate composting to increase agricultural production. Subsequently, other activities such as sloping land agriculture or double cropping could be introduced.

\subsubsection{Differences in Each Group's Consciousness of Decision Making and} Consciousness of Group Activities/Cooperation among Villagers

Employing the same method of discriminant function analysis, we analyzed differences in (b) consciousness of decision making and (c) consciousness of group activities/cooperation among villagers. Both groups were found to be correctly classified as follows: The overall correct classification rate was $69.2 \%$ for (b) (64.3\% of those categorized as URA without P; 18 out of 28 samples were classified correctly and $81.8 \%$ of those categorized as URA with P; 9 out of 11 samples were classified correctly) and the overall correct classification rate was $76.9 \%$ for (c) $71.4 \%$ of those categorized as URA without P; 20 out of 28 samples and 90.9\% of those categorized as URA with P; 10 out of 11 samples).

\subsubsection{Differences in Ethnic Groups from Three Variables (a) to (c)}

The categories "Hmong" and "Khmu" were similarly analyzed; 19 samples of Hmong and 20 samples of Khmu were used for analysis. Variable (a) which is related to the capability on sustaining livelihoods showed the overall correct classification rate $66.7 \%$ ( $75.0 \%$ of those categorized as Hmong; 11 out of 19 samples and $57.9 \%$ of those categorized as Khmu; 15 out of 20 samples). In the cases of variable (b) and (c) were; the overall correct classification rate $74.4 \%$ (75.0\% of those categorized as Hmong; 14 out of 19 samples and $73.7 \%$ of those categorized as Khmu; 15 out of 20 samples) and the overall correct classification rate $87.2 \%$ (85.0\% of those categorized as Hmong; 17 out of 19 samples and $89.5 \%$ of those categorized as $\mathrm{Khmu} ; 17$ out of 20 samples), respectively. These results revealed some notable differences in the variables analyzed. For example, the capability for decision making slightly differed $(p=0.39)$ between the Hmong (mean score was 2.45) and the Khmu (mean score was 1.89) according explanatory variables "b Expressing opinion (5 levels)" of Table 3, with Khmu 
individuals having fewer opportunities to participate in village discussions relating to land use or forest management than Hmong individuals.

The Khmu were found to be most affected to REDD plus implementation because lacking in almost every aspect of capability relating to livelihood maintenance and formulating and implementing forest management plans at the level of the village community. It is inappropriate manner to just impose the restriction by top down like conventional policy and measures in a view of safeguards (Ehara et al., 2014). Therefore, when initiating stakeholder consultations with local communities, supports should be made available for vulnerable groups such as the Khmu.

\subsubsection{Alternative Livelihood to Reduce Pressures on Forest Resources} A comprehensive summary of differences in capability by farming pattern and ethnicity was compiled based on the results of discriminant function analysis and individual interviews. In addition, supplemental information was obtained through individual interviews to assess the lack of capability (Table 6). "High" signified that sufficient capacity building was necessary and "Low" signified that capacity building was necessary, but not a priority. These factors were incorporated into the analysis of the degree of capacity building required for forest management and livelihood maintenance. The analysis revealed that Khmu farmers engaged in shifting cultivation for upland rice were most in need of capacity building in almost every area for ensuring their livelihood and participation in forest conservation.

The needs of improved livelihood and land use under the REDD plus, or potential alternative livelihood activities to promote the participation of local

Table 6. Summary of analyzed necessary capacity building for each group.

\begin{tabular}{|c|c|c|c|c|}
\hline \multirow{3}{*}{ Limited capability (necessity of capacity building) } & \multicolumn{4}{|c|}{ Group category } \\
\hline & \multicolumn{2}{|c|}{ Ethnicity } & \multicolumn{2}{|c|}{ Farming style } \\
\hline & $\begin{array}{c}\text { Khmu } \\
\text { (20 samples) }\end{array}$ & $\begin{array}{c}\text { Hmong } \\
\text { (21 samples) }\end{array}$ & $\begin{array}{l}\text { URF with P } \\
\text { (11 samples) }\end{array}$ & $\begin{array}{c}\text { URF without } \mathrm{P} \\
\text { (28 samples) }\end{array}$ \\
\hline \multicolumn{5}{|l|}{ (a) Sustaining livelihoods (farming techniques and resources) } \\
\hline Techniques for improving productivity & Middle & Middle & High & High \\
\hline Achieving necessary rice production (avoiding rice shortages) & High & None $^{\mathrm{a}}$ & Middle & Middle \\
\hline Agricultural water management & High & High & High & High \\
\hline \multicolumn{5}{|l|}{ (b) Capacity to formulate land use plans } \\
\hline Opportunity to participate in community discussions & High & Middle & Middle & High \\
\hline Expressing opinion in community & Middle & Middle & Low & Middle \\
\hline Identification of bottom-up decision making process & None $^{\mathrm{a}}$ & Low & None $^{\mathrm{a}}$ & None $^{\mathrm{a}}$ \\
\hline \multicolumn{5}{|c|}{ (c) Necessary capacity for implementing a land use plan and forest management } \\
\hline Cooperation between groups & Middle & Middle & Middle & High \\
\hline Identification of necessities and benefits from group activities & Middle & None $\mathrm{a}^{\mathrm{a}}$ & None $\mathrm{a}^{\mathrm{a}}$ & Middle \\
\hline
\end{tabular}

a. None means, they have enough capability and not necessary the capacity building. 
people in REDD plus summarized in Table 2, which includes sloping land agriculture and composting and so on. Such activities necessitate a change in the recent unsustainable/non-traditional farming styles of local communities. To improve community understanding and awareness, it is also necessary to introduce small-scale and short-term activities that positively reinforce newly introduced techniques through successful experiences. Livelihoods in the study site have traditionally based on shifting cultivation for upland rice, with alternative livelihoods being limited to livestock grazing. Consequently, local livelihoods are highly vulnerable to failed rice harvests. The results further indicated that on average, sample households suffered from rice shortages for 90 days per year. Potential improvements include not only increasing rice production by introducing new farming techniques, but also improving resilience through practices such as double cropping of vegetables (companion planting) and raising suitable livestock. These techniques should be combined in accordance with the capabilities and characteristics of each group within the community.

\section{Acknowledgements}

This study was supported by the Japan International Cooperation Agency (JICA) through "Validation and Registration of the Project on REDD plus through Participatory Land and Forest Management for Avoiding Deforestation in Lao PDR" and by the Ministry of the Environment, Japan through "REDD+ Study in LuangPrabang Province". We thank Mr. Kei Suzuki and Mr. Takashi Nanaumi (Japan Forest Technology Association) for their valuable advice and inputs.

\section{References}

Champa Lao (2012). Socio-Economic Study of Participatory Land and Forest Management Project for Reducing Deforestation (PAREDD) in Phonsay District (2011) Final Report. Vientiane: Champa.

Champa Lao (2015). Socio-Economic Study of Participatory Land and Forest Management Project for Reducing Deforestation (PAREDD) in Phonsay District (2014) Final Report. Vientiane: Champa.

Ehara, M., Hyakumura, K., \& Yokota, Y. (2014). REDD+ Initiatives for Safeguarding Biodiversity and Ecosystem Services: Harmonizing Sets of Standards for National Application. Journal of Forest Research, 19, 427-436.

https://doi.org/10.1007/s10310-013-0429-7

European Commission (2004). Aid Delivery Methods: Volume 1 Project Cycle Management Guidelines. Brussels: Europe Aid Cooperation Office.

Food and Agriculture Organization of the United Nations (FAO) (2010). Global Forest Resources Assessment 2010 Main Report. Rome: FAO.

Fujisaki, T., Hyakumura, K., Scheyvens, H., \& Cadman, T. (2016). Does REDD+ Ensure Sectoral Coordination and Stakeholder Participation? A Comparative Analysis of REDD+ National Governance Structures in Countries of Asia-Pacific Region. Forests, 7, 195. https://doi.org/10.3390/f7090195

Funakawa, S., Watanabe, T., Kadono, A., Nakao, A., Fujii, K., \& Kosaki, T. (2011). Soil Resources and Human Adaptation in Forest and Agricultural Ecosystems in Humid 
Asia. In World Soil Resources and Food Security (pp. 53-168). Boca Raton, FL: CRC Press.

Government of Lao PDR (2005). Forestry Strategy 2020. Vientiane: Government of Lao PDR.

Government of Lao PDR (2011). Readiness Preparation Proposal (R-PP) for Country: Lao People's Democratic Republic. Washington DC: Forest Carbon Partnership Facility (FCPF)-World Bank.

Government of Lao PDR (2015). Intended Nationally Determined Contribution (INDC). Bonn: UNFCCC.

Harris, N. L., Brown, S., Hagen, S. C., Saatchi, S. S., Petrova, S., Salas, W., Hansen, M. C., Potapov, P. V., \& Lotsch, A. (2012). Baseline Map of Carbon Emissions from Deforestation in Tropical Regions. Science, 336, 1573-1576.

https://doi.org/10.1126/science.1217962

Heinimann, A., Hett, C., Hurni, K., Messerli, P., Epprecht, M., Jørgensen, L., \& Breu, T. (2013). Socio-Economic Perspectives on Shifting Cultivation Landscapes in Northern Laos. Human Ecology, 41, 51-62. https://doi.org/10.1007/s10745-013-9564-1

Hiratsuka, M., Iwanaga, S., Tsuzuki, H., \& Yaginuma, H. (2014). Estimation of Potential GHG Emission Reduction through Corresponded REDD plus Activities in Remote Area in Central Kalimantan, Indonesia-Case Study in the Paduran Area. Open Journal of Forestry, 4, 338-348. https://doi.org/10.4236/ojf.2014.44040

Hiratsuka, M., Paudel, S. K., Iwanaga, S., Yaginuma, H., \& Masahiro, A. (2016). Prospects and Challenges of Reducing Emissions from Deforestation and Forest Degradation in Central Kalimantan Province, Indonesia. International Journal of Environment and Sustainable Development, 15, 49-66. https://doi.org/10.1504/IJESD.2016.073334

International Fund for Agricultural Development (IFAD) (2012). Country Technical Note on Indigenous People's Issues: Lao People's Democratic Republic. Rome: IFAD.

Japan International Cooperation Agency (JICA) (2014). Validation and Registration of the Project on REDD plus through Participatory Land and Forest Management for Avoiding Deforestation in Lao PDR Final Report. Tokyo: JICA.

Lestrelin, G., \& Giordano, M. (2007). Upland Development Policy, Livelihood Change and Land Degradation: Interactions from a Laotian Village. Land Degradation \& Development, 18, 55-76. https://doi.org/10.1002/ldr.756

Patel, T., Dhiaulhaq, A., Gritten, D., Yasmi, Y., De Bruyn, T., Paudel, N. S., Luintel, H., Khatri, D. B., Silori, C., \& Suzuki, R. (2013). Predicting Future Conflict under REDD+ Implementation. Forests, 4, 343-363. https://doi.org/10.3390/f4020343

Sen, A. (1992). Inequality Reexamined. Gloucestershire: Clarendon Press.

Umemiya, C., Wilamart, S., \& Amano, M. (2011). Increasing Participation in REDD-Plus: A Case Study from Nong Bua Lum Phu Province, North-Eastern Thailand. Thai Journal of Forestry, 30, 14-22.

United Nations Framework Convention on Climate Change (UNFCCC) (2007). Bali Action Plan-Decision 1/CP. 13. COP13. Bonn: UNFCCC.

United Nations Framework Convention on Climate Change (UNFCCC) (2011). The Cancun Agreements: Outcome of the Work of the Ad Hoc Working Group on LongTerm Cooperative Action under the Convention-Decision 1/CP.16. COP16. Bonn: UNFCCC.

Yamanoshita, M. Y., \& Amano, M. (2012). Capability Development of Local Communities for Project Sustainability in Afforestation/Reforestation Clean Development Mechanism. Mitigation and Adaptation Strategies for Global Change, 17, 425-440.

https://doi.org/10.1007/s11027-011-9334-6 
Submit or recommend next manuscript to SCIRP and we will provide best service for you:

Accepting pre-submission inquiries through Email, Facebook, LinkedIn, Twitter, etc. A wide selection of journals (inclusive of 9 subjects, more than 200 journals)

Providing 24-hour high-quality service

User-friendly online submission system

Fair and swift peer-review system

Efficient typesetting and proofreading procedure

Display of the result of downloads and visits, as well as the number of cited articles Maximum dissemination of your research work

Submit your manuscript at: http://papersubmission.scirp.org/

Or contact ojf@scirp.org 